\title{
Heterophile Antibody Measurement
}

National Cancer Institute

\section{Source}

National Cancer Institute. Heterophile Antibody Measurement. NCI Thesaurus. Code C81984.

The determination of the amount of heterophile antibodies present in a sample. 